\title{
Internet of Things: Smart Tourist Attraction Parking and Reservation on Industry 4.0
}

\author{
Ricky Firmansyah ${ }^{1}$ \\ \{ricky.rym@bsi.ac.id ${ }^{1}$ \} \\ AMIK BSI Bandung, Sekolah Internasional St. 1-6 Bandung, West Java, Indonesia ${ }^{1}$
}

\begin{abstract}
The increasing number of vehicles and tourism activities has increased the number of vehicles parked on the street so that it becomes a big problem. The importance of cloud and mobile computing for Industry 4.0 lies in the provision of services, which can be accessed globally via the Internet. This study proposes IoT smart tourist attractions parking using RFID that pinned on registered vehicle. The system will update the availability of parking lots when it is used. All information was processed on Arduino that is connected to the internet by using Wifi and storing data in the Cloud Firebase database. The results of this study are visitors will find parking information via Android. Smart tourist attractions parking can be used in several growing tourist attractions. It can reduce vehicle queues so it will reduce congestion, fuel consumption, air pollution, save time and money.
\end{abstract}

Keywords: android, industry 4.0, IOT, parking, tourism.

\section{Introduction}

The increasing number of vehicles and institutional activities (including tourism) in the city, temporarily or permanently has increased the number of vehicles parked on the street and official parking so that it becomes a big problem[1]. Searching for a vacant parking space in a metropolitan area is the daily concern for most drivers, and it is time consuming. It commonly results more traffic congestion and air pollution by constantly cruising in certain area only for an available parking space[2]. Hence this leads to annoying issue for the drivers to park their vehicles as it is very difficult to find a parking slot. The drivers usually waste time and effort and end up parking their vehicles finding a space on streets through luck. In worst case, people fail to find any parking space especially during peak hours and festive seasons[3]. In Indonesia, tourism sector/industry is one of the largest contributors in terms of foreign exchange if associated with economic sector. In 2013, according to the Ministry of Tourism, tourism sector ranked fourth in the category of foreign exchange earner after palm oil, coal, oil, and it produced 10,054.1 (in million USD). There is a tendency of increasing visiting rate (around 9-13\%) every year[4].

Lembang Sub-district has long been a tourist destination for travelers as nature and culinary attractions in West Bandung District, West Java Province, Indonesia. The interest of tourists can occur because the natural atmosphere of Lembang presents a very exotic and strategic scenery and cultural diversity on the transportation route. The tourist conditions of West Bandung District specially Lembang region have been widely publicized by the mass media through special and incidental coverage, on tourism and culinary feature programs. [5].

ICCSET 2018, October 25-26, Kudus, Indonesia

Copyright () 2018 EAI

DOI 10.4108/eai.24-10-2018.2280510 
So that tourist attractions in Lembang are now increasing rapidly which results the increasing number of vehicles. Severe traffic congestion always occurs at Lembang tourist attractions every weekend and holidays due to parking queues. Based on these issues, traffic congestion caused by vehicles looking for parking at tourist attractions needs to be considered. Today, parking at tourist attraction is still done by giving an entrance ticket and when checking out, the ticket checking is done to determine the amount of parking to be paid. There is no indication of parking on the ticket so that must visitors find available parking spaces themselves, resulting in irregular parking. The difficulty of determining the parking lot is full and still empty, it necessary have to a parking application that can answer the problems that occur to improve the service of visitors parking[6].

Here the challenge is to use the existing resources in the optimum level to reduce the searching time, traffic congestion in the city. Some embedded systems such as Arduino, Raspberry Pi, Tsgate, Tsmote etc. are used to develop the internet of things applications [7]. This study aims is to propose a smart parking system using RFID with Arduino Microcontroller that connected to the internet via Wifi using NodeMCU ESP-12 and can be accessed with Android device via smart tourist attractions parking application. Data storage is performed using Firebase cloud database technology. This smart parking system will be applied in one of the growing tourist attractions such as in the Lembang Sub-district, West Bandung District, West Java Province, Indonesia to face Industry 4.0 Era.

\subsection{Internet of Things and Industry 4.0}

Internet of Things (IoT) was first introduced by Kevin Ashton in 1999. Although it was introduced 19 years ago, until now there has been no global consensus on the definition of IoT. But in general, the concept of IoT is defined as the ability to connect intelligent objects and enable them to interact with other objects, the environment and other intelligent computing devices through the internet network. IoT in its various forms has begun to be applied to many aspects of human life. CISCO has even targeted that by 2020, 50 billion objects will be connected to the internet[8]. The phenomenon of Industry 4.0 was first mentioned in 2011 in Germany as a proposal for the development of a new concept of German economic policy based on high-tech strategies. The concept has launched the fourth technological revolution, which is based on the concepts and technologies that include cyberphysical systems, the Internet of things (IoT), and the Internet of services (IoS). The period of the fourth industrial revolution will be marked by the full automation and digitization processes, and the use of electronics and information technologies (IT) in manufacturing and services in a private environment. The consequences of the development of technologies such as 3D printing, the development of online sales services such as car services, medical examinations from home, ordering food directly sent from the store to the refrigerator, and so on, will have a significant impact on changes in small and mediumsized enterprises[9].

\subsection{Smart infrastructure and Smart Parking}

Smart infrastructure is smart devices are incorporated into buildings. They can improve flexibility, reliability, and efficiency in infrastructure operation. Their added value is in reduced costs and manpower requirements, as well as the enhancement of safety. Apple has developed a smartphone application for managing the "connected" home. Such applications allow control over door locks from remote devices from any Internet- 
connected source, as well as such things as adjusting a thermostat, controlling the supply of food in the refrigerator, and so on. They will have an important role in smart cities' mobility control (e.g., monitoring parking availability, traffic control). Industry 4.0 is based on mobile computing, cloud computing, and big data. The importance of cloud computing and mobile computing for Industry 4.0 lies in the provision of services, which can be accessed globally via the Internet. Services can easily be integrated and used [9]. Smart Parking systems obtain information about available parking spaces in a particular geographic area. This process is real-time to place vehicles at available positions. It involves real-time data collection using low-cost sensors and mobile-phone-enabled automated payment systems that allows people to reserve parking in advance[10].

\section{Method}

This study using experimental research method that are manipulating research or controls natural situations by making artificial conditions. This condition is made by the researcher[11]. This study proposes IoT smart tourist attractions parking system using RFID that pinned on registered cars in the parking system. Previously users must register through the android application, then book a parking lot on the desired date. After arriving at the tourist attractions parking area, RFID reader at the parking gate will read the on car RFID so the gate open automatically. The system will update the availability of parking lots when the parking lot is used. All information obtained by RFID was processed on Arduino that is connected to the internet by using Wifi and storing data in the Cloud Firebase database as shown in Fig. 1 below.

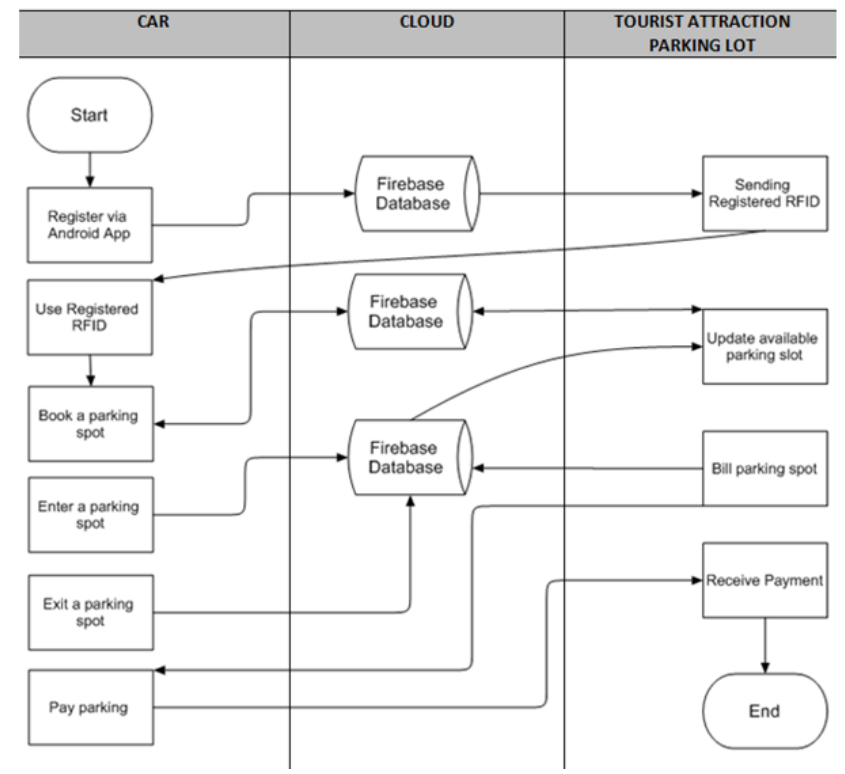

Fig. 1. Proposes Parking Activities Diagram. 
Parking lots will be made specifically for customers who make reservations. When the vehicle enters the parking area, the RFID reader will read RFID in the car. If according to booking data, the gate will open automatically and assume the vehicle has been parked so that the parking slot status is filled. This is also done using an ultrasonic sensor but this device can only be used in non-storey parking areas. The prototype of hardware unit and the block diagram is shown in Fig. 2 below.

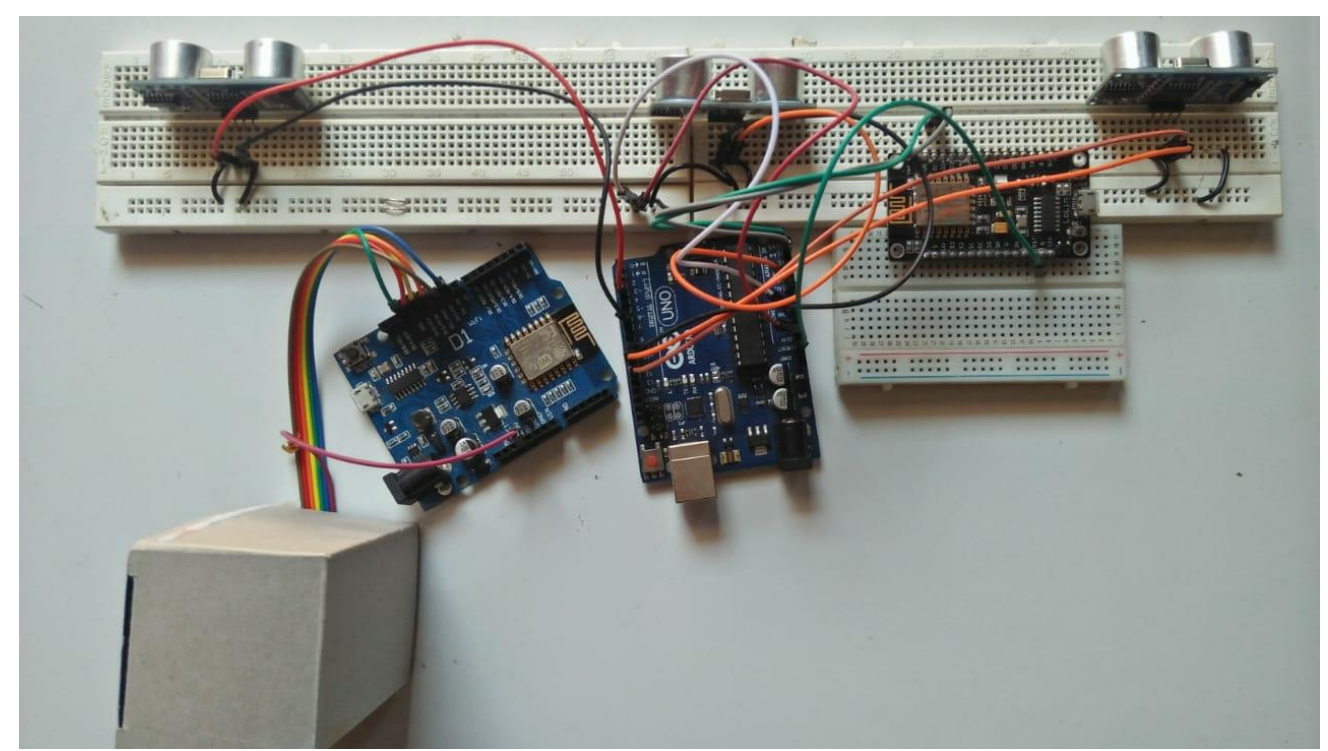

Fig. 2. Prototype hardware.

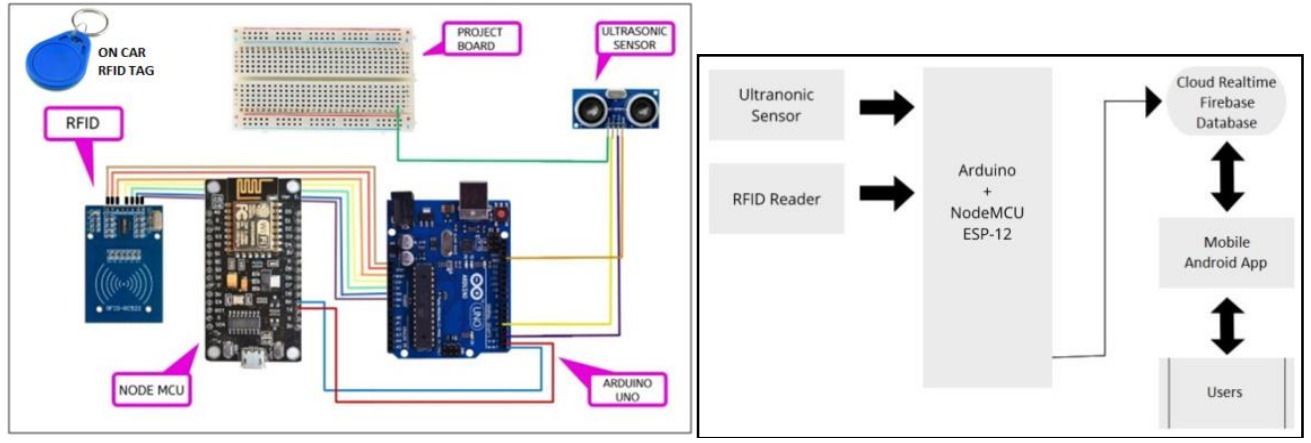

Fig. 3. Block Diagram.

Through the table below, we can see comparisons and differences between this study and other related studies. 


\begin{tabular}{|c|c|c|c|c|}
\hline Year & Author & Title & Findings & Method \\
\hline 2015 & Basavaraju & $\begin{array}{l}\text { Automatic Smart Parking } \\
\text { System using Internet of } \\
\text { Things (IOT) }\end{array}$ & $\begin{array}{l}\text { The most traffic occurs only because } \\
\text { of vehicle congestion in the urban } \\
\text { areas thus people are wasting time in } \\
\text { searching the parking area } \\
\text { abnormally to park their vehicles. }\end{array}$ & $\begin{array}{l}\text { Raspberry pi based parking sensor } \\
\text { which contains pi-camera to detect the empty } \\
\text { parking spaces and sends this data to server, } \\
\text { this stored data is accessed by Users using } \\
\text { Web Browser. }\end{array}$ \\
\hline 2016 & $\begin{array}{l}\text { Ramya, Sharmila, } \\
\text { Priyanka }\end{array}$ & $\begin{array}{l}\text { Smart Parking System } \\
\text { Using Intemet of Things } \\
\text { (IoT) }\end{array}$ & $\begin{array}{l}\text { System that could automatically } \\
\text { count when the car entering the } \\
\text { empty car space it actually has an } \\
\text { increase of budgeting in order to } \\
\text { install and to be maintained. }\end{array}$ & $\begin{array}{l}\text { Smart parking system using IR sensor, } \\
\text { Arduino Uno Microcontroller and Bluetooth } \\
\text { HC } 05 \text {. }\end{array}$ \\
\hline 2017 & $\begin{array}{l}\text { Gupta, Kulkami, } \\
\text { Jathar, Sharma, Jain }\end{array}$ & $\begin{array}{l}\text { Smart Car Parking } \\
\text { Management System } \\
\text { Using IoT }\end{array}$ & $\begin{array}{l}\text { Searching for a parking space is a } \\
\text { routine activity for many people in } \\
\text { cities around the world. This search } \\
\text { burns about one million barrels of } \\
\text { the world's oil everv dav. }\end{array}$ & $\begin{array}{l}\text { The proposed system will have Ultrasonic } \\
\text { sensor, Arduino } \\
\text { Uno, ESP8266-01 Wi-Fi Module, Cloud } \\
\text { server i.e. wwww.thingspeak.com, } \\
\text { User-End Application on Smartphone. }\end{array}$ \\
\hline 2018 & Firmansyah & $\begin{array}{l}\text { Internet of Things: Smart } \\
\text { Tourist Attraction } \\
\text { Parking and Reservation } \\
\text { on Industry } 4.0\end{array}$ & $\begin{array}{l}\text { The difficulty of determining the } \\
\text { parking lot is full and still empty at } \\
\text { tourist attractions results more traffic } \\
\text { congestion and air pollution }\end{array}$ & $\begin{array}{l}\text { Using RFID and Ultrasonic sensor with } \\
\text { Arduino Microcontroller that connected to } \\
\text { the internet via Wifi using NodeMCU ESP- } \\
12 \text { and can be accessed with Android device } \\
\text { via smart tourist attractions parking } \\
\text { application }\end{array}$ \\
\hline
\end{tabular}

Fig. 4. Table of Comparison and differences with Related Studies.

\section{$3 \quad$ Result}

The user interface provides a mechanism for users to interact with the application. Good design of the user interface is the most important part of making an application. The application is made to be user-friendly so users will be easy to learn and use the application[12]. To facilitate parking users, the Android application is made to implement this system with the interface design as shown in Figure 5.
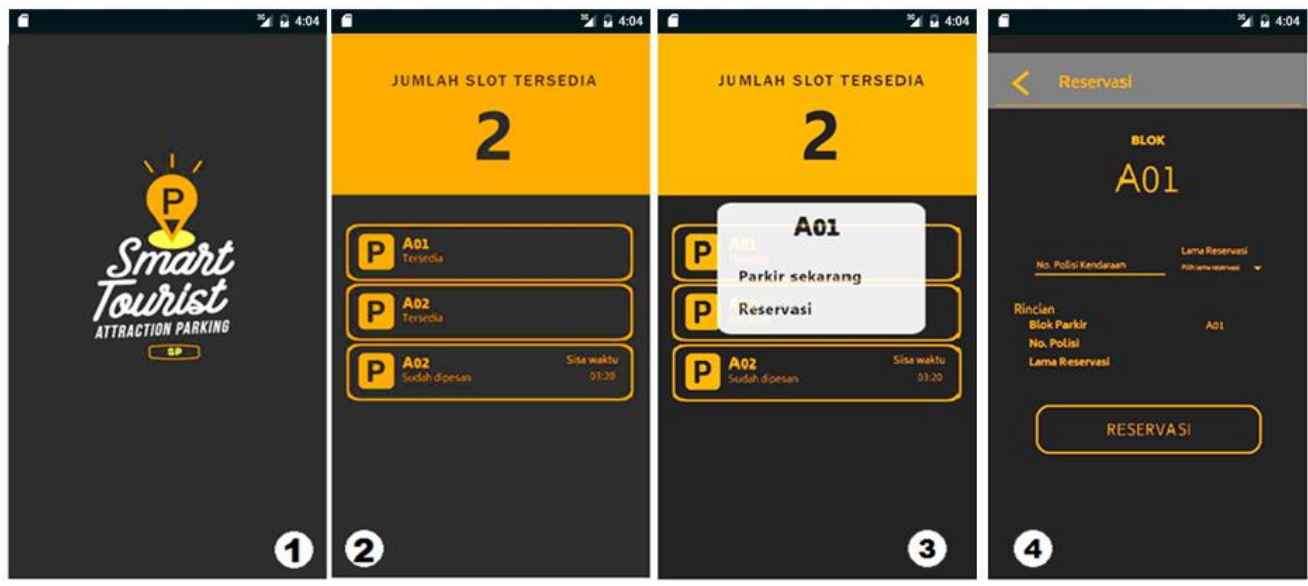

Fig. 5. Booking parking interface.

Information: 
1) Splashscreen interface will display when the application is run.

2) Avaiability parking lot page interface, it showing availability of parking lots.

3) We can choose an available parking space to order now or according to the desired time.

4) Booking parking detail interface, it display the details of our parking reservation.

After completing parking, the application will show the duration of the parking time and the amount that must be paid as shown in the Figure 6 below.

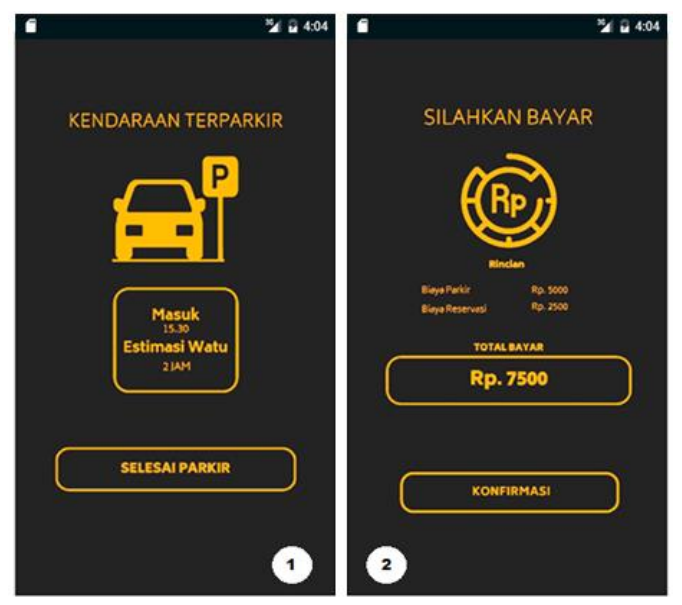

Fig. 6. Finished parking interface.

Information:

1) This interface showing duration of the parking time.

2) This interface showing the amount that must be paid.

\section{Conclusion}

Based on the smart tourist attractions parking system experiment, the following conclusions are obtained:

a. This smart tourist attractions parking system can be used in several growing tourist attractions such as in Lembang sub-district and other growing tourist attractions.

b. Visitors will find out the availability of parking spaces through the Android application. This enhances the user to check the status/availability of parking spaces before setting their journey.

c. Registered RFID requires users to buy RFID devices, so this method is suitable for customers who are subscribed parking member such as public transport/travel car or bus, returning visitors, although it can also occasionally come to visitors.

d. This device can only be used in non-storey parking areas. 
e. This smart tourist attractions parking system can reduce vehicle queues so it will reduce congestion, reduce fuel consumption, reduce air pollution, save time and money.

\section{References}

[1] M. J. K. M. Sharma, P. Prjapati, "Problem of Parking and their Possible Solutions with Special Reference to Kota City,” CPUH-Research J., pp. 18-24, 2017.

[2] M. P. and R. Sakore, "Smart Parking System Based On Reservation," Int. J. Sci. Eng. Res., vol. 2, no. 6, pp. 21-26, 2014.

[3] D. R. Y. Vishwanath, A. D. Kuchalli, "Survey paper on Smart Parking System based on Internet of Things," Int. J. Recent Trends Eng. Res., vol. 2, no. 3, pp. 156-160, 2016.

[4] S. M. and H. C. Hsieh, "Tourism Market and the Movement of Visitors in "Tourism Strategic Area' in Indonesia," TURIZAM, vol. 20, no. 1, pp. 34-47, 2016.

[5] F. F. A. R. Nugraha, S. Perbawasari, "Tourism Communication Model Based On Local Wisdom (Qualitative Descriptive Study in the Area Lembang, Regency of West Bandung)," THE MESSENGER, vol. 9, pp. 231-240, 2017.

[6] A. A. and A. Rahmadian, "Aplikasi Pengelolaan Parkir Kendaraan Dengan Menentukan Blok Parkir," J. CoreIT, vol. 3, pp. 35-40, 2017.

[7] B. Basavaraju, "Automatic Smart Parking System using Internet of Things (IOT)," Int. J. Sci. Res. Publ., vol. 5, pp. 629-632, 2015.

[8] O. Kharif, "8.pdf," Bloomberg.com, 2014. [Online]. Available: https://www.bloomberg.com/news/articles/2014-01-08/cisco-ceo-pegs-internet-of-things-as-19trillion-market.

[9] A. K. V. Roblek, M. Meško, “A Complex View of Industry 4.0,” SAGE Open, vol. 6, pp. 1-11, 2016.

[10] N. J. A. Gupta, S. Kulkarni, V. Jathar, V. Sharma, "Smart Car Parking Management System Using IoT,” Am. J. Sci. Eng. Technol., vol. 2, pp. 112-119, 2017.

[11] O. Blakstad, "11.pdf," Explorable.com, 2008. [Online]. Available: https://explorable.com/experimental-research.

[12] R. Firmansyah, "Usability Testing Dengan Use Questionnaire Pada Aplikasi Sipolin Provinsi Jawa Barat," Swabumi (Suara Wawasan Sukabumi), vol. 6, pp. 1-7, 2018. 